\title{
Enhancing the trustworthiness and credibility of HRD: Evidence-based management to the rescue?
}

\author{
Claire Gubbins \\ Brian Harney \\ Lisa van der Werff \\ Denise M. Rousseau
}

Please cite as:

Gubbins, C., Harney., B., van der Werff, L., and Rousseau, D. M.(2018) 'Enhancing the trustworthiness and credibility of HRD: Evidence-based management to the rescue?' Human Resource Development Quarterly, Vol 29(3), pp. 193-202

Keywords: evidence-based management; strategic business partner; trust; evidence-based HRD (EBHRD).

"Much of what is practiced [in HRD] day-to-day is still educated trial and error at best and 'the fad of the month' at worst. Few organizations or HRD consulting firms conduct research to test new approaches. And the academic research that has been conducted in the past five to ten years has probably still not been translated into practice. Imagine physicians learning the skill of surgery without understanding anatomy or physiology" (Chalofsky, 2007: 440).

HRD scholarship has made huge strides since its inception, evidenced by commentary in the silver anniversary of this journal (Ellinger, 2014; Russ-Eft, Watkins, Marsick, Jacobs \& McLean, 2014). Recent calls for further advancement of HRD have variously focused on definitional clarity (Werner, 2014), embracing multiple contexts (Short \& Gray, 2018), while offering prescriptions for more rigorous research (Anderson, 2017; Nimon \& Astakhova, 2015). Yet as the opening quote suggests, HRD has not yet made sufficient in-roads in demonstrating ability, competence and value (Kahnweiler, 2009). The Achilles heel of HRD remains the stakeholder perception, executives, managers and employees alike, that its costs (e.g. resource, time and financial investment) may outweigh benefits (e.g. learning, behavioral change, bottom-line impact) (Swanson, 1998). Considered reflection and the capability to explore and assess the evidence for current and new HRD approaches is

Gubbins, C., Harney., B., van der Werff, L., and Rousseau, D. M.(2018) 'Enhancing the trustworthiness and credibility of HRD: Evidence-based management to the rescue?' Human Resource Development Quarterly, Vol 29(3), pp. 193-202 
frequently lacking (Minbaeva, in press; Werner, 2014). As a consequence HRD fads are uncritically put into practice in ways that can destruct, rather than deliver or demonstrate, HRD's value (Chalofsky, 2007).

It is notable that while numerous professional competencies are expected for HRD, including the likes of instruction design, learning technologies, and coaching (see Arneson, Rothwell, \& Naughton, 2013), HRD professionals seldom display, collect or assess evidence of such competence. No surprise that Russ-Eft et al., (2014: 7) recently called out 'HRD ability' as a HRD deficiency, noting 'accountability and evaluation continue to be of concern'. In this editorial we make the case for evidence-based HRD (EBHRD) as a means for HRD practitioners to demonstrate their professional competencies and enhance stakeholder support. Evidence-based HRD (EBHRD) is a process of decision making which is grounded in the best available scientific evidence and business information and informed by critical thinking and evaluation (Rousseau \& Barends, 2011). With this focus our arguments align with those of the HR professional body, the Chartered Institute of Personnel and Development (CIPD): 'future people professionals will need to have the competency and desire to explore different sources of information to inform their decisions, and to help evidence decisions for key stakeholders' (2017: 32). The essence of our argument is that engaging with EBHRD helps HRD practitioners enhance their credibility, trustworthiness and professionalism in the eyes of key stakeholders.

The basis of HRD status, power and impact stems from a demonstrated competence in informing, influencing and managing stakeholder relationships (Tsui, 1990). Here the trackrecord of HRD is open to doubt. Although the argument for HRD as a strategic contributor has intuitive appeal (e.g. Swanson, 1993) the absence of an HRD presence at top management levels or on company boards suggests an empty claim (Claus \& Collison, 2005). The influence of strategic decision makers is recognized as crucial to effective HRD (Gilley \& Coffern, 1994), yet negative stakeholder perceptions and lack of support undermine HRD effectiveness (Fricker, 1994). The prolonged battle for strategic business partner status is evidence of a 'credibility crisis' (Aldrich, Dietz, Clark, \& Hamilton, 2015), 'fragility' (Keegan \& Francis, 2010) and professional 'self-doubt' (Ulrich, Younger, Brockband, \& Ulrich, 2013). Moreover, even where the status of strategic business partner is attained, HRD

Gubbins, C., Harney., B., van der Werff, L., and Rousseau, D. M.(2018) 'Enhancing the trustworthiness and credibility of HRD: Evidence-based management to the rescue?' Human Resource Development Quarterly, Vol 29(3), pp. 193-202 
staff and employees can experience feelings of frustration and isolation (Hope-Hailey et al., 2005; Harrington, Rayner \& Warren, 2012).

In practice, HRD partnerships should be one of mutual influence (Wang, 2003) which also attends to the needs, demands and evidence coming from other stakeholders, especially employees. Enhanced employee credibility is likely to enable and reinforce the communication and enactment of key and relevant HRD messages (Bowen \& Ostroff, 2004). Overall, HRD needs to secure the confidence and commitment of a range of internal (e.g. managers, employees, functional specialists, line managers) and external (e.g. policy makers, professional bodies) stakeholders. The benefits of demonstrating HRD competency includes connecting into the network of key decision makers (Gubbins \& Garavan, 2016), greater credibility in the eyes of line managers (Watson \& Maxwell, 2007), and having greater influence and input from employees. This serves to eliminate the vicious circle whereby HRD, consumed by remedying initial people development problems, find themselves on a constant, reactive 'back-foot' (cf Guest \& King, 2004).

Advancing HRD competence necessitates a greater focus on the processes of how the HRD professionals (re)gain credibility and trustworthiness regarding the strategic value they add, while also acknowledging the complex and socially dynamic context in which they act (Truss et al., 2002). This requires progression beyond pure content-based approaches (e.g. typologies such as Ulrich type strategic business partner models) and/or proxy measures of HRD competence and influence (e.g. board membership), to attend to the pragmatic realities of actually enacting roles and achieving influence and impact, or what Pritchard (2010) refers to as 'the social construction or performance of strategic HR[D] identity'. We propose that evidence-based HRD (EBHRD) holds the potential for real-time, aggregate insights enabling constant and critical evaluation of organizational activities. This infrastructure is heralded as a platform to elevate the status and influence of HRD affording the profession both the time and critical inputs for in-depth insights on critical skills, progress and results (Minbaeva, in press).

Below we detail the value of a trust perspective in capturing the credibility challenge confronting HRD as it deals with key stakeholders, including top management. We then outline the prospective role of EBHRD as a means to enhance trustworthiness and a vehicle

Gubbins, C., Harney., B., van der Werff, L., and Rousseau, D. M.(2018) 'Enhancing the trustworthiness and credibility of HRD: Evidence-based management to the rescue?' Human Resource Development Quarterly, Vol 29(3), pp. 193-202 
to offer independent grounded insights that demonstrate the competency and value delivered by HRD. Our final section is a call to action for HRD research that aligns with the principles of EBHRD, including exploring the facilitators and barriers to its practice.

\section{Trust in HRD}

Trust is an essential ingredient in positive work relationships, a "social glue" promoting social interaction (Lewis \& Weigert, 2012). As a psychological state representing a willingness to be vulnerable to another party based on positive expectations of their behavior (Rousseau, Sitkin, Burt, \& Camerer, 1998), meta-analytic evidence has demonstrated the importance of trust for a range of individual and organizational outcomes (Colquitt, Scott, \& LePine, 2007; De Jong, Dirks, \& Gillespie, 2016). In attempting to fulfill their roles as strategic partners with top management and champions of the employees that they represent, HRD must balance trusting relationships across stakeholders whose interests at times diverge and compete (Gubbins \& Garavan, 2016) - a balance difficult to maintain. Evidence highlights a credibility and trust crisis that undermines HRD's ability to wield influence with senior management and be recognized as a profession that adds value beyond administrative and operational support (Aldrich et al., 2015; Claus \& Collison, 2005; Gold, Rogers, \& Smith, 2003). Adopting a strategic business partner role, closely aligned at board level, enhances credibility and furthers top management acceptance of HRD as a profession (Wright, McMahan, McCormick, \& Sherman, 1998). Unfortunately, adopting this stance may lead to neglect of employee needs, undermining employee trust and destroying any credibility HR draws from its ethical and social roles in the organization (Graham \& Tarbell, 2006; Harrington et al., 2012; Kochan, 2004; Wylie, Sturdy \& Wright, 2014).

Lack of trust from key stakeholders represents a significant problem for the HRD profession. In working relationships where trust is deficient, individuals are less likely to take risks (Mayer, Davis, \& Schoorman, 1995; De Jong \& Dirks, 2012) or share information and other resources (Ferrin, Bligh, \& Kohles, 2007). Because top management are gatekeepers of financial resources, strategic information and access to policy decisions, HRD influence is often directly dependent on the quality of its relationship with the top management (Tsui,

Gubbins, C., Harney., B., van der Werff, L., and Rousseau, D. M.(2018) 'Enhancing the trustworthiness and credibility of HRD: Evidence-based management to the rescue?' Human Resource Development Quarterly, Vol 29(3), pp. 193-202 
1990; Ferris \& Judge, 1991). HRD practitioners need top management support to secure key resources (Chapman, 2004), as well as final approval and support for its interventions and change efforts (Gilley, Maycunich, \& Quatro, 2002; Tjepkema et al., 2002). Equally, the trust of employees as engaged participants is critical in HRD initiatives. It enables employees to learn and develop by providing a safe environment for taking risks (Baer, van der Werff, Colquitt, Rodell, Zipay, \& Buckley, in press). Trust has been found to be particularly significant for employees when assessing the competencies of HRD (Graham \& Tarbell, 2006) and for evaluating the effectiveness of HRD activity (Mayer \& Davis, 1999; Robinson, 1996).

How can HRD professionals build trust with important stakeholders? Research supports adopting three attributes (Mayer et al., 1995): 1) Ability, HRD skills and knowledge to contribute effectively in meeting needs and goals of stakeholders 2) Benevolence - HRD sensitivity to stakeholder interests and goals in decisions and interventions, 3) Integrity HRD consistency in adherence to principles stakeholders can accept. Signaling trustworthiness across these three categories puts HRD's stakeholder relationships on a strong foundation. EBHRD is a powerful means by which to signal these characteristics and does so in a way that tackles the challenge of balancing stakeholder interests.

\section{Towards Evidence-Based HRD and HRD Trustworthiness}

One mechanism to build perceptions of HR trustworthiness across stakeholder groups is for HRD professionals to adopt an evidence-based and data- driven approach to their work. The use of multiple sources of high quality evidence in wider HRD practice can directly impact perceptions of a practitioner's professionalism and conscientiousness (Rousseau \& Barends, 2011). Professionalism entails a degree of competency and adherence to wellspecified standards. Similarly, conscientiousness is comprised of traits such as competence, care, dutifulness (i.e. adherence to standards of conduct), organization, self-discipline and deliberation (Costa, McCrae, \& Dye, 1991). A perception that a HRD practitioner displays both these qualities promotes attributions of ability and integrity. Moreover, combined with thoughtfulness, dutifulness and care in HRD practice, these qualities shape the extent key stakeholders perceive HRD as benevolent.

Gubbins, C., Harney., B., van der Werff, L., and Rousseau, D. M.(2018) 'Enhancing the trustworthiness and credibility of HRD: Evidence-based management to the rescue?' Human Resource Development Quarterly, Vol 29(3), pp. 193-202 
Scientific evidence supports our argument. Aldrich et al. (2015) show that the availability and use of valid methodologies and metrics to analyze the impact of HR initiatives are critical factors in establishing the HR credibility in the eyes of senior managers. One interviewee commented ".....you get credibility by being able to reference the world inside and outside and that includes using metrics... Otherwise you are just using your intuition and you can't validate it" (Aldrich et al., 2015: p. 122). Measures of efficiency, including financial measures, appear to be particularly influential in building HR credibility and use of such metrics have been suggested as a first step in enabling HR to communicate the value of other strategic but less familiar HR measures (Lawler \& Boudreau, 2015). Results from Gubbins, Harney, van der Werff (2018) suggests that where top management perceive HR and HRD (HR/D) professionals to use evidence based practices, they also report greater perceptions of HR/D professionals' ability, benevolence, integrity and likelihood of strategic business partnership.

\section{What is Evidence Based Practice HRD (EBHRD)?}

Evidence-based practice is the conscientious use of best available information in the practice of management, paying careful attention to the quality of evidence available from science, the organizational setting, its stakeholders, and practitioner experience in making decisions (Barends \& Rousseau, 2018). It offers a number of complementary avenues through which HRD professionals can enhance their decision making, inform their practices and enhance the trust and esteem with which they are held by their key stakeholders. Specifically, it proposes the use of four sources of evidence: scientific findings, stakeholder values and concerns, organizational data (facts, reports and observations) and professional judgment. First, with regard to scientific findings, the capacity to appropriately address current people development challenges resides in the capacity to "deploy scientific knowledge regarding what works" (Rousseau \& Barends, 2011: 221). Yet while there is general agreement that HR and HRD represents a body of knowledge (Claus \& Collison, 2005; Chalofsky, 2007 ), practitioners tend to remain ill-informed about the large cumulative bodies of scientific evidence related to their day to day practice (Lawler, 2007; Rynes, Colbert, \& Brown, 2002). Nonetheless, familiarity and comfort in accessing this body of evidence is likely to have a

Gubbins, C., Harney., B., van der Werff, L., and Rousseau, D. M.(2018) 'Enhancing the trustworthiness and credibility of HRD: Evidence-based management to the rescue?' Human Resource Development Quarterly, Vol 29(3), pp. 193-202 
meaningful impact on HRD's display of competence and professionalism in dealing with top management. The second source of evidence, attention to stakeholder issues and concerns represents "a key feature of comprehensive, evidence-based decision practices" (Rousseau \& Barends, 2011: 225) and this is particularly important given HRD's role in serving multiple stakeholders. EBHRD involves incorporating multiple evidence sources (Pfeffer \& Sutton, 2006) including all stakeholders who may be impacted by decisions or interventions (Briner et al., 2009: 19). The explicit inclusion of stakeholder perspectives in this way offers HRD an avenue to communicate their benevolence to those affected by their decisions and to do so in a systematic manner that builds perceptions of their ability and integrity. Stakeholder inclusion and involvement also fosters buy-in and greater psychological ownership, a precondition for effective HRD (Wognum \& Lam, 2000).

Third, with respect to organizational data, barriers to becoming a strategic business partner become surmountable when HRD "regularly presents documented enhancement of performance" (Swanson, 1993: 123). A key challenge for HRD has been to present metrics that assess HRD processes and practices from a strategic perspective. Generally, efficiency, effectiveness and impact are the three metrics collected in order to understand HR's impact on business strategy and performance (Boudreau \& Ramstad, 2003). The most common are efficiency metrics such as productivity and cost metrics such as training expenses per employee. Such metrics do not address effectiveness of HR services or impact on important organizational measures. For example, effectiveness metrics would consider whether training resulted in skills development and transfer to the job. Impact metrics evaluate the impact of HRD programs on the organization's performance. It is not simply about more HRD-related measures but rather providing the right metrics and using good analytical models in order to test and demonstrate effects of HR practices on organizational effectiveness (Lawler et al., 2004; Boudreau \& Ramstad, 2003). In this regard, Barends \& Rousseau (2018) advise development of organization-specific logic models to combine information about inputs, activities and outcomes related to HR and management decisions. HR analytics enabled by information technology uses descriptive, visual, and statistical analyses of data related to HR processes, human capital, organizational performance, and external economic benchmarks in order to enable data-driven decision-making (Marler \& Boudreau, 2017). HR analytics would

Gubbins, C., Harney., B., van der Werff, L., and Rousseau, D. M.(2018) 'Enhancing the trustworthiness and credibility of HRD: Evidence-based management to the rescue?' Human Resource Development Quarterly, Vol 29(3), pp. 193-202 
benefit from closer adherence to the evidence based practice principles in shifting focus from analysis of easily available HR-related data to developing valid and relevant metrics to analyze a valid business challenges (Barends \& Rousseau. 2018; Rasmussen \& Ulrich, 2015). Beginning to develop relevant logic models regarding an organization's effects on stakeholders and ultimate performance outcomes offers a process for developing valid inhouse metrics that inform key decisions and provide inimitable competitive advantage. Doing this, will arguably build greater perceptions of both HRD professionals ability and integrity as it demonstrates a skill set that is both relevant to, and in line with, practices that are common across other divisions such as finance, accounting and sales.

Fourth is professional experience and judgment of practitioners, managers, consultants, which is accumulated repeated practice, feedback and reflection over time, otherwise known as the tacit knowledge of professionals (Rousseau \& Barends, 2011). Professional judgment is important in deciding how to evaluate and apply the evidence gathered (Rousseau \& Barends, 2011). Wright, Zammuto, Liesch, Middleton, Hibbert, Burke \& Brazil (2016) find that personal experience and judgment of practitioners is needed in the handling, adaptation and communication of the evidence obtained since it cannot speak for itself and is of no merit in decision processes or in applications sensitive to context and conditions of use. Effective use of evidence in the form of HRD interventions that deliver impact, ultimately shapes how stakeholders perceive HR/D professionals. Additionally, it is found that evidence based practice is enacted through the interplay between the rational processes of reviewing scientific literature, analyzing data and drawing on professional tacit knowledge and intuition to 'cross-pollinate' and make sense of the patterns within and across the different types of data (Wright et al., 2016). Thus trust in HR/D professional's ability to engage in such a process is central to the success of evidence based practice and its potential impact on their trustworthiness.

To date, research suggests little strategic use of EBHRD and HR analytics (Rasmussen \& Ulrich, 2015; Gubbins, Harney \& van der Werff, 2018; Lawler \& Boudreau, 2015) by HRD professionals despite its advocacy by academics and practice leaders for the past 15 years (Angrave et al., 2016). We note that use of an appropriate evidence base and analytics fails to make the list of key competencies typically required of HR/D professionals

Gubbins, C., Harney., B., van der Werff, L., and Rousseau, D. M.(2018) 'Enhancing the trustworthiness and credibility of HRD: Evidence-based management to the rescue?' Human Resource Development Quarterly, Vol 29(3), pp. 193-202 
(Arneson, Rothwell, \& Naughton, 2013). This failure is usually attributed to the fact that those receiving the information lack the cognitive frameworks to make sense of evidence (such as understanding how an engagement score or a turnover rate connects to business success) (Lawler \& Boudreau, 2015) or lack the type of analytic and data based decisionmaking capability needed to influence business strategy (Lawler, Levenson \& Boudreau, 2004). Although HR analytics may offer an opportunity to demonstrate strategic impact, the appropriate conditions are needed to develop this capability. EBHRD may provide a critical opportunity to ask valid and important questions related to business strategy. Asking relevant and appropriate questions is the precursor of all effective use of evidence and data (Barends \& Rousseau, 2018; Sackett et al., 2000). In line with this, we propose that use of EBHRD will significantly impact stakeholder perceptions of the ability benevolence and integrity of HRD professionals and their potential to build effective partnerships with both top management and employees in their organizations.

\section{A call to action for EBHRD}

EBHRD is not simply about practice but involves a shift of mindset (Briner et al., 2009). Following Chalofsky's analogy it is not enough for HRD practitioners "to know the concepts of the discipline; they must also be constantly inquiring into and critiquing the concepts" (2007: 436). In capturing the implications of our argument, we purposefully frame our thinking and recommendations via the thought logic that underpins evidence-based management (i.e. ask, acquire, appraise, aggregate, apply and assess). This ensures a systematic and considered reflection which will hopefully serve as a transparent template to guide future endeavors (Aguinis, Ramani, and Alabduljader, 2018). Our recommendations are captured in Table 1 and elaborated upon below.

Insert Table 1 about here

\section{The questions we should ask}

The process-based approach outlined in this editorial stresses the value of further exploring the inter-relationships between HRD professionals and key stakeholders. Issues center on how HRD professionals can demonstrate competence in order to enhance their credibility and trustworthiness across stakeholders. Arguably, much research to date focuses

Gubbins, C., Harney., B., van der Werff, L., and Rousseau, D. M.(2018) 'Enhancing the trustworthiness and credibility of HRD: Evidence-based management to the rescue?' Human Resource Development Quarterly, Vol 29(3), pp. 193-202 
on the demographic profiling of HRD professionals and the nature of their roles to the neglect of capabilities (e.g. analytic capability) that may demonstrate their value (Minbaeva, in press). A key question also concerns the key motivating and inhibiting factors informing the uptake of EBHRD.

\section{The evidence we should acquire}

We recommend the practice of engaged scholarship (Van de Ven, 2005). This involves sense-checking assumptions and research questions to see whether they resonate with practical realities (for a detailed overview of better integrating research with practice see Gubbins \& Rousseau, 2015). Relevant here is consideration of the appropriate stakeholder groups. Frequently research relies on single person respondents which risks bias. Much greater depth of insight comes from the comparison of perspectives. This approach moves to better capture prospective conflicting views and areas of consensus about value add, thereby providing much richer insight on organizational phenomenon. A recent example comes from our own research in this area (Gubbins et al., 2018) where we were approached by the professional body (Irish Institute for Training and Development) to explore the issue of HRD professionals having greater strategic influence. We engaged in a partnership approach to define the problem and explore key issues, sense checking our questions with practitioners prior to research design, and furthering the conversation via a presentation and breakout discussions to $250 \mathrm{HRD}$ professionals at the IITD annual conference. It is also important to have a holistic appreciation of key stakeholders impacted by HRD. Too often HRD agendas and associated competencies are defined narrowly or with exclusive attention to one stakeholder group, usually top management. In practice requirements, perspectives and credibility dimensions will vary across stakeholders (Graham \& Tarbell, 2006).

\section{Appraising data sources}

In advocating that HRD practice become more evidence-based, we call attention to the need for HRD scholars to help create more systematic reviews of the empirical and scientific research literature related to HRD practice. Practitioners can only readily use the best available, peer-reviewed scientific evidence to inform and support their decisions, if they

Gubbins, C., Harney., B., van der Werff, L., and Rousseau, D. M.(2018) 'Enhancing the trustworthiness and credibility of HRD: Evidence-based management to the rescue?' Human Resource Development Quarterly, Vol 29(3), pp. 193-202 
can find it. For example, in examining the HRD strategic business partner position, a number of relevant meta-analyses have been published in the domains of trust (Colquitt, Scott, \& Le Pine, 2007; DeJong, Dirks, \& Gillespie, 2016; Dirks \& Ferrin, 2002), the impact of sophisticated HR practices on performance (Combs, Ketchen, Hall, \& Liu, 2006; Jiang, Lepak, Hu, and Baer, 2012), including training on productivity (Kim \& Ployhart, 2014). There also exists substantive summaries of evidence (e.g. Locke, 2009) and increasingly extensive global communities of practice (http://www.evidencebased-management.com and https://scienceforwork.com). That said, we need more HRD-specific systematic reviews and meta-analyses of scientific research to add EBHRD practice (Gubbins \& Rousseau, 2015: 115). In a similar vein, evidence from multiple HRD stakeholders is also frequently lacking in organizations including both employees and line management (Harney \& Jordan, 2008).

Evidence in studies can equally be assessed as per the criteria of internal and external validity (reduced bias), reliability (consistent measurement), and impact (effect size) and the hierarchy of scientific evidence (see Rousseau \& Barends, 2011). In this regard there is considerable scope for improvement in research methodologies in the HRD field. For example, Tharenou, Saks \& Moore (2007) found a number of weaknesses in the methodologies employed in research on the training and organizational performance relationship; half of studies used subjective measures of organizational performance, threequarters were cross-sectional, while one third of the studies used single item measures of training. In essence, both HRD professionals and researchers need the best available evidence to establish their credibility and add value to organizations (Minbaeva, in press).

\section{Application and Assessment}

Application includes consideration of how results can be best presented to make a legitimate case. Frequently academic articles fail to translate findings in forms that practitioners find useful. Yet actionable results are a critical means of argument and persuasion, especially when convincing more senior levels (Minbaeva, in press). For practitioners, beyond the benefit of content, sound application is likely to confer prestige, professionalism and conscientiousness (Rousseau \& Barends, 2011). This can help with persuasion, especially when providing recommendations that do not align with existing

Gubbins, C., Harney., B., van der Werff, L., and Rousseau, D. M.(2018) 'Enhancing the trustworthiness and credibility of HRD: Evidence-based management to the rescue?' Human Resource Development Quarterly, Vol 29(3), pp. 193-202 
approaches or are innovative in terms of design or delivery. In working through application and assessment, valid technique is built on experimentation and learning. Assessment of interventions is typically where organizations fall-short. Having a base or pre-intervention point enables direct benchmarking and assessment without which establishing causality and return on investment becomes impossible.

Gubbins, C., Harney., B., van der Werff, L., and Rousseau, D. M.(2018) 'Enhancing the trustworthiness and credibility of HRD: Evidence-based management to the rescue?' Human Resource Development Quarterly, Vol 29(3), pp. 193-202 
Table 1 A call to action for Evidence Based HRD

\begin{tabular}{|c|c|c|}
\hline Evidence Based Logic & Operationalized as & Application to our argument \\
\hline Ask & $\begin{array}{l}\text { Problem } \\
\text { definition/translation }\end{array}$ & $\begin{array}{l}\text { HRD credibility and trustworthiness crisis } \\
\text { What can HRD professionals do to bridge this perceptual gap to attain influence } \\
\text { and credibility? } \\
\text { Significance of process and relational understanding (beyond content approaches). } \\
\text { What are the facilitators and inhibitors of EBHRD? }\end{array}$ \\
\hline Acquire & $\begin{array}{l}\text { Search for and } \\
\text { retrieve evidence }\end{array}$ & $\begin{array}{l}\text { Comparing perspectives of. HRD Professionals, top management, employees, } \\
\text { other functions } \\
\text { HR/Training professional and policy bodies. } \\
\text { Consult key stakeholders, including employees, managers and senior leaders. } \\
\text { Develop competencies in gathering quality stakeholder evidence by learning how } \\
\text { best to get representative information from different stakeholder groups. }\end{array}$ \\
\hline Appraise & $\begin{array}{l}\text { Assess the } \\
\text { trustworthiness of } \\
\text { available evidence } \\
\text { base }\end{array}$ & $\begin{array}{l}\text { Use of the 'best' available scientific evidence e.g. meta-analysis, systematic } \\
\text { literature reviews. } \\
\text { Critically evaluating research methodology (internal and external validity, } \\
\text { reliability, and impact). } \\
\text { Learn how to evaluate the quality of stakeholder evidence, in terms of } \\
\text { representiveness and interpretation of both quantitative and qualitative findings. } \\
\text { Engage with global communities of practice (e.g. https://www.cebma.org/; } \\
\text { https://scienceforwork.com). }\end{array}$ \\
\hline Apply and Assess & Solution oriented & $\begin{array}{l}\text { Produce actionable knowledge to be incorporated/leveraged for HRD decision } \\
\text { making/framing/positioning. } \\
\text { Help management understand how to integrate information from different }\end{array}$ \\
\hline
\end{tabular}

Gubbins, C., Harney., B., van der Werff, L., and Rousseau, D. M.(2018) 'Enhancing the trustworthiness and credibility of HRD: Evidence-based management to the rescue?' Human Resource Development Quarterly, Vol 29(3), pp. 193-202 


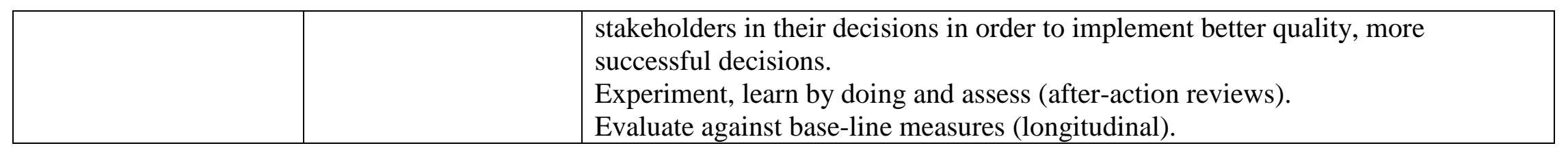

Gubbins, C., Harney., B., van der Werff, L., and Rousseau, D. M.(2018) 'Enhancing the trustworthiness and credibility of HRD: Evidence-based management to the rescue?' Human Resource Development Quarterly, Vol 29(3), pp. 193-202 


\section{Funding acknowledgement}

Brian Harney would like to acknowledge funding received from the European Union's Horizon 2020 research and innovation programme under Marie Sklodowska-Curie grant agreement No 734824.

\section{References}

Aguinis, H., Ramani, R., \& Alabduljader, N. (2018). What you see is what you get? Enhancing methodological transparency in management research. Academy of Management Annals, 12(1), 83-110. doi.org/10.5465/annals.2016.0011

Aldrich, P., Dietz, G., Clark, T., \& Hamilton, P. (2015). Establishing HR professionals' influence and credibility: Lessons from the capital markets and investment banking sector. Human Resource Management, 54(1), 105-130. doi: 10.1002/hrm.21626

Anderson, V. (2017). Criteria for evaluating qualitative research, Human Resource Development Quarterly, 28, 125-133. doi: 10.1002/hrdq.21282

Angrave, D., Charlwood, A., Kirkpatrick, I., Lawrence., M \& Stuart, M. (2016). HR and analytics: why HR is set to fail the big data challenge, Human Resource Management Journal, 26(1), 1-11. doi: 10.1111/1748-8583.12090

Arneson, J., Rothwell, W., \& Naughton, J. (2013). Training and development competencies redefined to create competitive advantage. TandD, 67(1), 42-47.

Baer, M., van der Werff, L., Colquitt, J. A., Rodell, J. B., Zipay, K., \& Buckley, F. (in press). Trusting the "look and feel": Situational normality, situational aesthetics, and the perceived trustworthiness of organizations. Academy of Management Journal, Advanced online publication.

Barends, E., \& Rousseau, D.M. (2018). Evidence-based management. London: Kogan Page.

Boudreau, J.W., \& Ramstad, P.M. (2003). Strategic HRM measurement in the 21st century: From justifying HR to strategic talent leadership. In M. Goldsmith, R. P. Gandossy, \& M. S. Efron (Eds), HRM in the 21st century (pp. 79-90). New York: John Wiley.

Bowen, D., \& Ostroff, C. (2004). Understanding HRM-performance linkages: The role of the 'strength' of the HRM system. Academy of Management Review, 29, 202-222. doi: 10.5465/AMR.2004.12736076

Briner, R., Denyer, D., \& Rousseau, D. M. (2009). Evidence based management: Concept clean up time? Academy of Management Perspectives, 23(4), 19-32. doi: 10.5465/AMP.2009.45590138

Chalofsky, N. (2007). The seminal foundation of the discipline of HRD: People, learning, and organizations. Human Resource Development Quarterly, 18, 431-442. doi: 10.1002/hrdq. 1212

Chapman, D. D. (2004, March). Preferences of training performance measurement: A comparative study of training professionals and non-training managers. Paper presented at the Academy of Human Resource Development Conference, Austin, TX.

CIPD (2017). Human capital analytics and reporting: exploring theory and evidence. Research report. London: Chartered Institute of Personnel and Development. Retrived from https://www.cipd.co.uk/knowledge/strategy/analytics/human-capital-analyticsreport

Claus, L., \& Collison, J. (2005). The maturing profession of human resources: World wide and regional view survey report. USA: SHRM.

Colquitt, J. A., Scott, B. A., \& LePine, J. A. (2007). Trust, trustworthiness, and trust propensity: a meta-analytic test of their unique relationships with risk taking and job 
performance. Journal of Applied Psychology, 92, 909-927. doi: 10.1037/00219010.92.4.909

Combs, J. G., Ketchen, D., Hall, A., \& Liu, Y. (2006). Do high performance work practices matter? A meta-analysis of their effects on organisational performance. Personnel Psychology, 59, 501-528. doi: 10.1111/j.1744-6570.2006.00045.x

Costa, P. T., Jr., McCrae, R. R., \& Dye, D. A. (1991). Facet scales for agreeableness and conscientiousness: A revision of the NEO personality inventory. Personality and Individual Differences, 12, 887-898. doi: 10.1016/0191-8869(91)90177-D

De Jong, B. A., \& Dirks, K. T. (2012). Beyond shared perceptions of trust and monitoring in teams: implications of asymmetry and dissensus. Journal of Applied Psychology, 97, 391-406. doi: 10.1037/a0026483

De Jong, B. A., Dirks, K. T., \& Gillespie, N. (2016). Trust and team performance: A metaanalysis of main effects, moderators, and covariates. Journal of Applied Psychology, 101,1134-1150. doi: 10.1037/apl0000110

Ellinger, A. D. (2014). Celebrating 25 years of HRD scholarship: Happy silver anniversary, Human Resource Development Quarterly, 25(1), 1-3. doi: 10.1002/hrdq.21178

Ferrin, D. L., Bligh, M. C., \& Kohles, J. C. (2007). Can I trust you to trust me? A theory of trust, monitoring, and cooperation in interpersonal and intergroup relationships. Group and Organization Management,32, 465-499. doi: $10.1177 / 1059601106293960$

Ferris, G. R., \& Judge, T. A. (1991). Personnel/human resources management: A political influence perspective. Journal of Management, 17, 447-488. doi: $10.1177 / 014920639101700208$

Fricker, J. (1994). Training for change: An investment in people. In J. Prior (Ed.), Gower handbook of training and development (pp. 21-31). Hampshire, UK: Gower.

Gilley, J. W., \& Coffern, A. J. (1994). Internal consulting for HRD professionals: Tools, techniques and strategies for improving organizational performance. New York: McGraw Hill.

Gilley, J. W., Maycunich, A., \& Quatro, S. A. (2002). Comparing the roles, responsibilities, and activities of transactional versus transformational roles in HRD. Performance Improvement Quarterly, 15(4), 23-44. doi: 10.1111/j.1937-8327.2002.tb00263.x

Gold, J. Rogers, H., \& Smith, V. (2003). What is the future for the human resource development professional? A UK perspective. Human Resource Development International, 6(4), 437-456. doi: 10.1080/1367886022000016046

Graham, M., \& Tarbell, L. (2006). The importance of the employee perspective in the competency development of human resource professionals. Human Resource Management, 45(3), 337-355. doi: 10.1002/hrm.20116

Gubbins, C., Harney, B., \& van der Werff, L. (2018, January). Are we data-driven strategic HR/D business partners? Exploring $\mathrm{C}$ suite and HR/HRD professional perspectivespreliminary results. TandD Magazine, 63, 1014.https://www.iitd.ie/KnowledgeCentre/TDMagazine.aspx

Gubbins, C., \& Garavan, T. (2016). Social capital effects on the career and development outcomes of HR professionals. Human Resource Management, 55(2), 241-260. doi: 10.1002/hrm.21727

Gubbins, C., \& Rousseau, D. M. (2015). Embracing translational HRD research for evidencebased management: Let's talk about how to bridge the research practice gap. Human Resource Development Quarterly, 26(2), 109-125. doi: 10.1002/hrdq.21214

Guest, D., \& King, Z. (2004). Power, innovation and problem-solving: the personnel managers' three steps to heaven? Journal of Management Studies, 41, 401-423. doi: 10.1111/j.1467-6486.2004.00438.x 
Harney, B., \& Jordan., C. (2008). Unlocking the black box: Line managers and HRM performance in a call centre context. International Journal of Productivity and Performance Management, 57, 275-296. doi: 10.1108/17410400810867508

Harrington, S., Rayner, C., \& Warren, S. (2012). Too hot to handle? Trust and human resource practitioners' implementation of anti-bullying policy. Human Resource Management Journal, 22(4), 392-408. doi: 10.1111/1748-8583.12004

Hope Hailey, V., Farndale, E., \&Truss, C. (2005). The HR department's role in organisational performance. Human Resource Management Journal, 15(3), 49-66. doi: 10.1111/j.1748-8583.2005.tb00153.x

Jiang, K., Lepak, D., Hu, J., \& Baer, J. (2012). How does human resource management influence organizaional outcomes? A meta-analytic investigation of mediating mechanisms. Academy of Management Journal, 55(6), 1264-1294. doi: 10.5465/amj.2011.0088

Kahnweiler, W. M. (2009). HRD as a profession: Current status and future directions. Human Resource Development Quarterly, 20, 219-229. doi: 10.1002/hrdq.20011

Keegan, A., \& Francis, H. (2010). Practitioner talk: the changing textscape of HRM and emergence of HR business partnership. International Journal of Human Resource Management, 21, 873-898. doi: 10.1080/09585191003729341

Kochan, T. A. (2004). Restoring trust in the human resource management profession. Asia Pacific Journal of Human Resources, 42, 132-146. doi: 10.1177/1038411104045352

Kim, Y., \& Ployhart, R.E. (2014). The effects of staffing and training on firm productivity and profit growth before, during and after the Great Recession. Journal of Applied Psychology, 99(3), 361-389. doi: 10.1037/a0035408

Lawler, E. E. (2007). Why HR practices are not evidenced based. Academy of Management Journal, 50, 1033-1036. doi: 10.5465/AMJ.2007.27155013

Lawler, E. E., \& Boudreau, J. W. (2015). Global trends in human resource management: A twenty year analysis, California; Stanford University Press.

Lawler, E.J., Levenson, A., \& Boudreau, J.W. (2004). HR metrics and analytics- Uses and impacts, Centre for Effective Organizations Publication G 04-8 (460), Retrieved from Marshall School of Business, University of Southern California website: https://ceo.usc.edu/hr-metrics-and-analytics-uses-and-impacts/

Lewis, J. D., \& Weigert, A. J. (2012). The social dynamics of trust: Theoretical and empirical research, 1985-2012. Social Forces, 91(1), 25-31. doi: 10.1093/sf/sos116

Locke, E. A. (2009). Handbook of principles of organizational behavior: Indispensable knowledge for evidence-based management. New York: Wiley.

Marler, J.H., \& Boudreau, J.W. (2017). An evidence-based review of HR analytics. The International Journal of Human Resource Management, 28(1), 3-26. doi: 10.1080/09585192.2016.1244699

Mayer, R. C., \& Davis, J. H. (1999). The effect of the performance appraisal system on trust for management: A field quasi-experiment. Journal of Applied Psychology, 84(1), 123-136. doi: 10.1037/0021-9010.84.1.123

Mayer, R. C., Davis, J. H., \& Schoorman, F. D. (1995). An integrative model of organizational trust. Academy of Management Review, 20(3), 709-734. doi: 10.5465/AMR.2007.24348410

Minbaeva, D. (in press). Building credible human capital analytics for organizational competitive advantage. Human Resource Management. Advanced online publication. doi: $10.1002 / \mathrm{hrm} .21848$.

Nimon, K. F., \& Astakhova, M. (2015). Improving the rigor of quantitative HRD research: Four recommendations in support of the general hierarchy of evidence. Human Resource Development Quarterly, 26, 231-247. doi: 10.1002/hrdq.21219 
Pfeffer, J., \& Sutton, R. (2006). Hard facts dangerous half truths \& total nonsense. Boston MA: Harvard Business School Press.

Pritchard, C. (2010). Becoming an HR strategic partner: tales of transition. Human Resource Management Journal, 20(2), 175-188. doi: 10.1111/j.1748-8583.2009.00107.x

Rasmussen, T., \& Ulrich, D. (2015). Learning from practice: how HR analytics avoids being a management fad. Organizational Dynamics, 44, 236-242. doi:

10.1016/j.orgdyn.2015.05.008

Robinson, S. L. (1996). Trust and breach of the psychological contract. Administrative Science Quarterly, 574-599. doi: 10.2307/2393868

Rousseau, D. M., \& Barends, E. (2011). Becoming an evidence-based HR practitioner. Human Resource Management Journal, 21(3), 221-235. doi: 10.1111/j.17488583.2011.00173.x

Rousseau, D. M., Sitkin, S. B., Burt, R. S., \& Camerer, C. (1998). Not so different after all: A cross-discipline view of trust. Academy of Management Review, 23(3), 393-404. doi: 10.5465/AMR.1998.926617

Russ-Eft, D., Watkins, K. E., Marsick, R. L., Jacobs, G., \& McLean, G. (2014). What do the next 25 years hold for HRD research in areas of our interest?. Human Resource Development Quarterly, 25(1), 5-27. doi: 10.1002/hrdq.21180

Rynes, S. L., Colbert, A. E., \& Brown, K. G. (2002). HR professional's beliefs about effective human resource practices: Correspondance between research and practice Human Resource Management, 41(2), 149-174. doi: 10.1002/hrm.10029

Sackett, D.L., Straus, S.E., Richardson, W.C., Rosenberg, W., \& Haynes, R.M. (2000). Evidence-based medicine: How to practice and teach EBM. New York: Churchill Livingstone.

Short, H. J., \& Gray, D. (2018). HRD in SMEs: A research agenda whose time has come. Human Resource Development Quarterly, 29(1), 7-13. doi: 10.1002/hrdq.21305

Swanson, R. A. (1993). Business partner: a HRD mandate. Human Resource Development Quarterly, 4, 121-123. doi: 10.1002/hrdq.3920040202

Swanson, R. A. (1998). Demonstrating the financial benefit of HRD: Status update on theory and practice. Human Resource Development Quarterly, 9, 285-295. doi: 10.1002/hrdq.3920090307

Tharenou, P., Saks, A. M., \& Moore, C. (2007). A review and critique of research on training and organizational-level outcomes. Human Resource Management Review, 17(3), 251-273. doi: 10.1016/j.hrmr.2007.07.004

Tjepkema, S., Stewart, J., Sambrook, S., Mulder, M., ter Hoerst, H., \& Scheerens, J.(2002). $H R D$ and learning organisations in Europe. London: Routledge.

Truss, C., Gratton, L., Hope Hailey, V., Stiles, P., \& Zaleska, K. (2002). Paying the piper: Choice and constraint in changing HR functional roles. Human Resource Management Journal, 12(2), 39-63. doi: 10.1111/j.1748-8583.2002.tb00063.x

Tsui, A. (1990). A multiple constituency model of organizational effectiveness: An empirical examination at the human resource subunit level. Administrative Science Quarterly, 35, 458-483. doi: 10.2307/2393313

Ulrich, D., Younger, J., Brockband, W., \& Ulrich, M. (2013). The state of the HR profession. Human Resource Management, 52(3), 457-471. doi: 10.1002/hrm.21536

Van de Ven, A. (2005). Engaged scholarship: A guide for organisational and social research. Oxford: Oxford University Press.

Wang, G. G. (2003). On the two-way customer service model in HRD practice. Human Resource Development Review, 2, 453-458. doi: 10.1177/1534484303258040 
Watson,. S., \& Maxwell, G., (2007). HRD from a functionalist perspective: The views of line managers, Advances in Developing Human Resources, 9(1), 31-41. doi: $10.1177 / 1523422306294493$

Werner, J. (2014). Human resource development $\neq$ human resource management: So what is it? Human Resource Development Quarterly, 25, 127-139. doi: 10.1002/hrdq.21188

Wognum, I., \& Lam, J. F. (2000). Stakeholder involvement in strategic HRD aligning: The impact on HRD effectiveness, International Journal of Training and Development, 4(2), 99-110. doi: 10.1111/1468-2419.00099

Wright, P., McMahan, G., McCormick, B., \& Sherman, W. S. (1998). Strategy, core competence, and HR involvement as determinants of HR effectiveness and refinery performance. Human Resource Management, 37(1), 17-29. doi: 10.1002/(SICI)1099050X(199821)37:1<17::AID-HRM3>3.0.CO;2-Y

Wright, A.L., Zammuto, R.F., Liesch, P.W., Middleton, S., Hibbert, P., Burke, J., \& Brazil, V. (2016). Evidence-based management in practice: Opening up the decision process, decision maker and context. British Journal of Management, 27, 161-178. doi: 10.1111/1467-8551.12123

Wylie, N., Sturdy, A., \& Wright, C. (2014). Change agency in occupational context: Lessons for HRM. Human Resource Management Journal, 24(1), 95-110. doi: 10.1111/17488583.12028 